\title{
Seasonal variations of some hematochemical parameters in Holstein bovine under the same livestock conditions
}

\author{
Raúl D. Cerutti', María C. Scaglione', Francesca Arfuso², Maria Rizzo², \\ and Giuseppe Piccione ${ }^{2 *}$
}

${ }^{1}$ Department of Veterinary Sciences, Universidad Nacional del Litoral, Santa Fe, Argentina

${ }^{2}$ Department of Veterinary Sciences, Polo Universitario dell'Annunziata, University of Messina, Messina, Italy

\begin{abstract}
CERUTTI, R. D., M. C. SCAGLIONE, F. ARFUSO, M. RIZZO, G. PICCIONE: Seasonal variations of some hematochemical parameters in Holstein bovine under the same livestock conditions. Vet. arhiv 88, 309-321, 2018.
\end{abstract}

ABSTRACT

In this study, the effect of season, gender and productive status on some hematochemical parameters was evaluated in clinically healthy Holstein cattle. A total of 18 bovines were enrolled in the study and equally divided in three groups, according to their gender and lactation class: Group A (dairy cows in first lactation class); Group B (dairy cows in third lactation class); Group C (bulls). Groups A and B were in the same productive period (dry period in winter, early lactation in spring, mild lactation in summer, end of lactation in autumn). Samples were collected of the animals' blood at the same time of the day (8:00) in January (winter season), April (spring season), July (summer season) and October (autumn season), and concentrations of glucose, calcium $(\mathrm{Ca})$, magnesium $(\mathrm{Mg})$, potassium $(\mathrm{K})$, sodium $(\mathrm{Na})$, phosphorus $(\mathrm{P})$, total protein, albumin, creatinine, urea, aspartate aminotransferase (AST), alanine aminotransferase (ALT) were evaluated. A seasonal effect $(\mathrm{P}<0.05)$ was found for $\mathrm{Mg}$, creatinine, urea and glucose values in all Groups; $\mathrm{Ca}, \mathrm{Na}, \mathrm{K}, \mathrm{AST}, \mathrm{ALT}$, triglycerides and cholesterol values were influenced by season in Group $\mathrm{C}(\mathrm{P}<0.05)$. Productive status affected $\mathrm{Ca}, \mathrm{AST}$, ALT, triglycerides and cholesterol values $(\mathrm{P}<0.05)$ in Groups A and B; gender significantly influenced AST and ALT values $(\mathrm{P}<0.05)$. This study suggests that seasonal and physiological conditions have to be taken into consideration for correct interpretation of serum chemistry in bovine, in order to establish an accurate interpretation of laboratory data, which is critical in the diagnosis, prognosis and treatment of diseases.

Key words: cattle; biochemical parameters; gender; productive status; season

\section{Introduction}

The production and reproduction performance of an animal depends not only on the flow of energy, food and water within the animal's biological system, but also on

\footnotetext{
*Corresponding author:

Prof. Giuseppe Piccione, Department of Veterinary Sciences, University of Messina, Polo Universitario dell'Annunziata, 98168, Messina, Italy, Phone: +39 0903503 584; Fax: +39 0903503 975; E-mail: giuseppe.piccione@unime.it
} 
its adaptability to the environment in which it lives. The variations in environmental variables such as ambient temperature, relative humidity, wind and rainfall, have been recognized as potential hazards in livestock growth and production.

Serum chemistry is important for the diagnosis, treatment and prognosis of diseases. Determination of metabolic blood profiles, including serum mineral and biochemical parameters, is very important for evaluation of normal physiological status of animals and in helping the evaluation of management practices, nutrition and health status (OPARA et al., 2010). Deficiency of minerals, as well as perturbation of the main biochemical parameters, may result in decreased immunity and productivity, and compromised health status and reproductive performance.

In order to interpret biochemical data correctly and to identify anomalous situations in a given dairy herd, the results obtained in the laboratory from blood analysis must be compared with values corresponding to healthy animals, the so-called reference values (HERDT, 2000).

We hypothesized that gender, productive status and environmental variables represent endogenous and exogenous factors which could influence the biochemical parameters in bulls and dairy cows. Therefore, as previously suggested (MBASSA and POULSEN, 2003; SWANSON et al., 2004; MAZZULLO et al., 2014; ALBERGHINA et al., 2013; ARFUSO et al., 2016) there is a need to investigate these factors and how they affect the animals' hematochemistry, in order to establish an accurate interpretation of laboratory data, which is critical in the diagnosis, prognosis and treatment of diseases in cattle. In view of these considerations, the aim of the present study was to evaluate whether electrolytes and some hematochemical parameters are influenced by season, gender and productive status in bulls and dairy cows in the first and third lactation classes.

\section{Materials and methods}

This study was carried out on 18 clinically healthy Holstein bovines belonging to an agricultural establishment located in the town of Villa Trinidad, Argentina (Santa Fe, longitude $26^{\circ} 13^{\prime}$ and latitude $\left.58^{\circ} 17^{\prime}\right)$. All the animals enrolled in the study were clinically healthy with no evidence of disease and free from internal and external parasites. Their health status was evaluated on the basis of rectal temperature, heart rate, respiratory rate, appetite, fecal consistency and hematological profile. Fresh fecal samples were examined according to the MC MASTER Method based on protocols previously described by MAFFA (1989).

The animals were divided into three groups according to their gender and lactation classes: Group A $(n=6)$ were dairy cows in the first lactation class, aged 2 years with a mean body mass of $500 \pm 25 \mathrm{~kg}, \mathrm{BCS}=3.50 \pm 0.25$; Group B $(\mathrm{n}=6)$ were dairy cows in the third lactation class, aged 4 years with a mean body mass of $550 \pm 25 \mathrm{~kg}, \mathrm{BCS}=3.50$ 
\pm 0.25 ; Group $\mathrm{C}(\mathrm{n}=6)$ were bulls, aged 2 years with a mean body mass of $520 \pm 25 \mathrm{~kg}$, $\mathrm{BCS}=3.75 \pm 0.25$. The cows in Groups A and B had the same gestational and productive period. In particular, the cows were in the dry period in winter, early lactation in spring, mild lactation in summer, end of lactation in autumn. During production the dairy cows were milked twice a day at the same time of the day $(05: 00 \mathrm{~h}$ and 15:00 h). All the animals were raised under uniform pasture conditions, they were subject to natural variations in the light-dark cycle and they had free access to natural shade. The animals were under an extensive management system allowing them to move in an outdoor grazing area with pasture planted with alfalfa, and water was available ad libitum. The farm was selected with milk production (about $10.000 \mathrm{~kg} /$ year); milk yield quality did not differ between the cows: it had an average of $3.7 \%$ of milk-fat and $3.4 \%$ of milk-protein. The protocol of this study was reviewed and approved in accordance with the standards recommended by the Guide for the Care and Use of Laboratory Animals, and Directive 2010/63/EU.

From each fasting animal blood samples were collected every three months by jugular venipuncture into tubes containing EDTA, and into tubes without anticoagulant agent. Blood sampling was performed at the same time of the day (8:00) in January (winter season), April (spring season), July (summer season) and October (autumn season). Immediately after collection, the blood samples were placed in refrigerated bags and transported to the laboratory for analysis. EDTA whole blood samples were processed in the laboratory within 2 hours for evaluation of blood glucose concentration by means of a small hand-held meter (Accutrend Plus ${ }^{\circledR}$, Roche Diagnostics, Switzerland). The blood samples collected into tubes without anticoagulant agent were centrifuged at $1.780 \mathrm{~g}$ for $10 \mathrm{~min}$. The serum samples obtained were refrigerated at $+4{ }^{\circ} \mathrm{C}$ and analyzed within $24 \mathrm{~h}$ in order to evaluate the concentrations of calcium $(\mathrm{Ca})$, magnesium $(\mathrm{Mg})$, potassium $(\mathrm{K})$, sodium $(\mathrm{Na})$, phosphorus $(\mathrm{P})$, total protein, albumin, creatinine, urea, aspartate aminotransferase (AST) and alanine aminotransferase (ALT), by means of an automated analyzer (Metrolab 2100, Laboratorio Rodriguez Corswant SRL, Argentina) using commercially available kits.

At the same time as the blood collection, thermal and hygrometric records were made for the whole study by means of a data logger, with high reading accuracy and resolution (Model Tinytag Ultra 2, Gemini Data Logger, West Sussex, United Kingdom). A temperature-humidity index (THI), used as an indicator of thermal comfort for cattle, was calculated using the U.S. Weather Bureau's Temperature Humidity Index Formula for bovine species (POTTER and JACOBSEN, 2000):

$\mathrm{THI}\left[{ }^{\circ} \mathrm{C}\right]=\mathrm{T}^{\circ}$ ambient $+(0.36 *$ point of steam condensation $)+41.5$

Statistical analysis. Data, expressed as mean values \pm standard deviation $( \pm \mathrm{SD})$, were tested for normality using the Shapiro-Wilk normality test. All data were normally distributed $(\mathrm{P}>0.05)$ and statistical analysis was performed. A general linear model (GLM) 
for repeated measures was applied to assess significant the effect of the experimental conditions (season, gender and productive status) on the studied parameters. When significant differences were found, Bonferroni's post hoc comparison was applied. P values $<0.05$ were considered statistically significant.

Statistical analysis was performed using the STATISTICA software package (STATISTICA 7, Stat Software Inc., Tulsa, Oklahoma).

\section{Results}

The environmental temperature, relative humidity and THI observed during the monitoring period are shown in Fig. 1. Statistical analysis showed that season, productive status and gender significantly influenced the values of the parameters considered most in bulls and dairy cows (Figs. 2, 3 and 4). In particular, the statistically significant effect of season $(\mathrm{P}<0.05)$ was found on $\mathrm{Mg}$, creatinine, urea and glucose values in all Groups; whereas the values of $\mathrm{Ca}, \mathrm{Na}, \mathrm{K}, \mathrm{AST}, \mathrm{ALT}$, triglycerides and cholesterol were statistically influenced by season only in bulls (Group C).
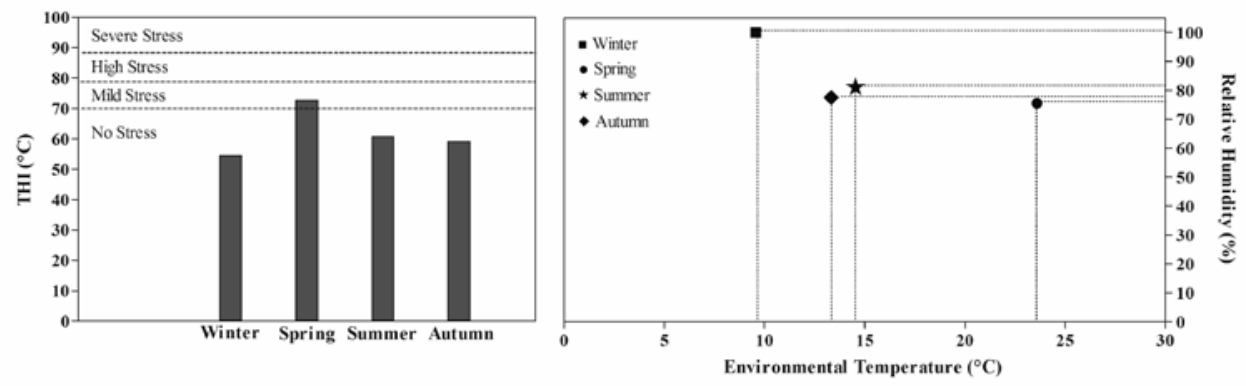

Fig. 1. Mean values of environmental temperature, relative humidity and temperature-humidity index (THI) recorded during the different seasons (winter, spring, summer and autumn)

A statistically significant effect of productive status $(\mathrm{P}<0.05)$ was found on Ca, AST, ALT, triglycerides and cholesterol values in the cows in the first and third lactation (Group A and Group B, respectively). A statistically significant influence of gender $(\mathrm{P}<0.05)$ was found on the values of AST and ALT. No statistically significant effect of season, productive status and gender $(\mathrm{P}>0.05)$ was found on $\mathrm{P}$, total proteins and albumin values (Table 1). No statistically significant differences were found between Group A and Group $\mathrm{B}$ regarding any of the studied parameters $(\mathrm{P}>0.05)$. 
R. D. Cerutti et al.: Effect of season on some hematochemical parameters in Holstein bovine
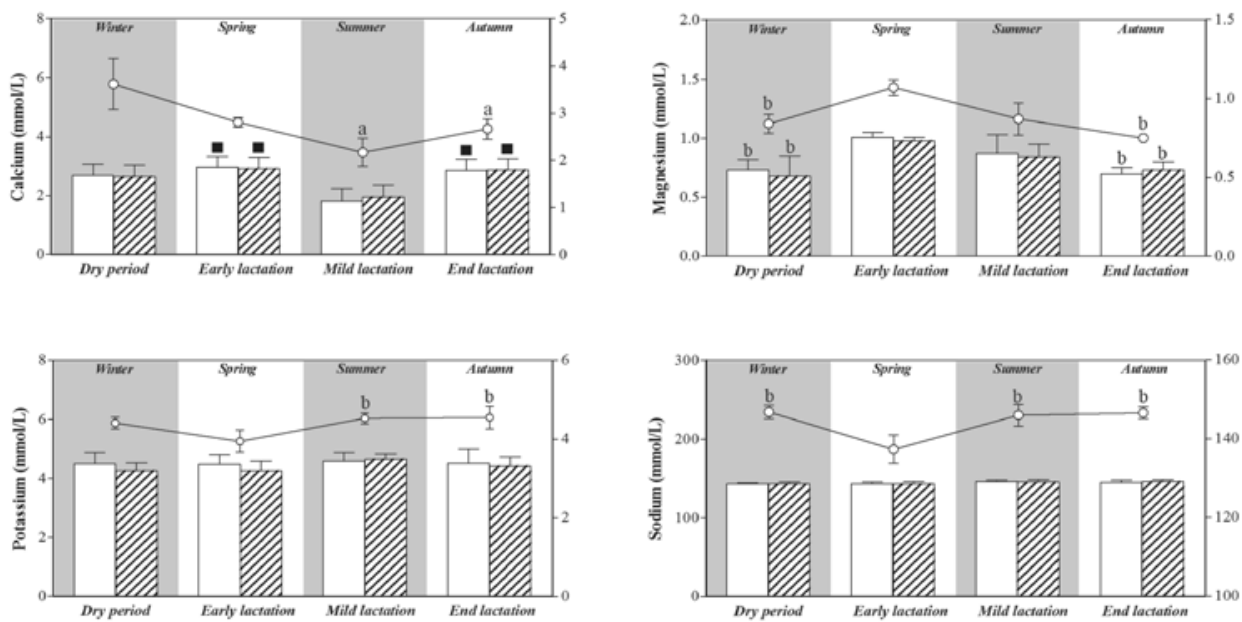

Significant effect of season $(P<0.05)$ : ${ }^{\mathrm{a}} \mathrm{vs}$ Winter; ${ }^{\mathrm{b}} \mathrm{vs}$ Spring Significant effect of reproductive status $(P<0.05)$ : * vs Mild lactation

$\square$ Group A $\square$ Group B -O- Group C

Fig. 2. Mean values \pm standard deviation $( \pm \mathrm{SD}$ ) of serum calcium, magnesium, potassium and sodium concentrations obtained from dairy cows in the first lactation class (Group A), cows in the third lactation class (Group B) and bulls (Group C) during the monitored period (winter - dry period; spring - early lactation; summer - mild lactation; autumn - end lactation) with the related statistical significances

Table 1. Mean values \pm standard deviation ( \pm SD) of serum phosphorus, total proteins and albumin concentrations obtained from dairy cows in the first lactation class (Group A), cows in the third lactation class (Group B) and bulls (Group C) during the monitored period (winter - dry period; spring - early lactation; summer - mild lactation; autumn - end lactation)

\begin{tabular}{|c|c|c|c|c|}
\hline \multicolumn{2}{|c|}{} & \multicolumn{3}{|c|}{ Parameters } \\
\hline \multirow{3}{*}{ Groups } & Seasons & Phosphorus (mmol/L) & Total protein $(\mathrm{g} / \mathrm{L})$ & Albumin $(\mathrm{g} / \mathrm{L})$ \\
\hline \multirow{3}{*}{ A } & Winter & $1.74 \pm 0.40$ & $70.92 \pm 2.47$ & $39.14 \pm 0.73$ \\
\cline { 2 - 5 } & Spring & $2.13 \pm 0.16$ & $67.12 \pm 2.07$ & $37.56 \pm 1.36$ \\
\cline { 2 - 5 } & Summer & $1.73 \pm 0.29$ & $76.80 \pm 4.09$ & $37.92 \pm 2.02$ \\
\cline { 2 - 5 } & Autumn & $1.88 \pm 0.13$ & $71.13 \pm 8.50$ & $39.21 \pm 1.30$ \\
\hline \multirow{3}{*}{ B } & Winter & $1.87 \pm 0.08$ & $74.98 \pm 1.64$ & $39.16 \pm 0.84$ \\
\cline { 2 - 5 } & Spring & $2.02 \pm 0.07$ & $69.17 \pm 3.92$ & $38.90 \pm 0.59$ \\
\cline { 2 - 5 } & Summer & $1.77 \pm 0.28$ & $75.78 \pm 6.72$ & $37.09 \pm 2.05$ \\
\cline { 2 - 5 } & Autumn & $1.87 \pm 0.19$ & $69.09 \pm 8.16$ & $38.29 \pm 1.44$ \\
\hline
\end{tabular}


R. D. Cerutti et al.: Effect of season on some hematochemical parameters in Holstein bovine

Table 1. Mean values \pm standard deviation $( \pm \mathrm{SD}$ ) of serum phosphorus, total proteins and albumin concentrations obtained from dairy cows in the first lactation class (Group A), cows in the third lactation class (Group B) and bulls (Group C) during the monitored period (winter - dry

period; spring - early lactation; summer - mild lactation; autumn - end lactation) (continued)

\begin{tabular}{|c|c|c|c|c|}
\hline \multicolumn{2}{|c|}{} & \multicolumn{3}{|c|}{ Parameters } \\
\hline \multirow{2}{*}{ Groups } & Seasons & Phosphorus (mmol/L) & Total protein $(\mathrm{g} / \mathrm{L})$ & Albumin $(\mathrm{g} / \mathrm{L})$ \\
\hline \multirow{3}{*}{$\mathrm{C}$} & Winter & $2.01 \pm 0.17$ & $70.01 \pm 1.95$ & $39.15 \pm 0.39$ \\
\cline { 2 - 5 } & Spring & $1.88 \pm 0.20$ & $65.81 \pm 3.11$ & $37.89 \pm 1.99$ \\
\cline { 2 - 5 } & Summer & $1.68 \pm 0.14$ & $69.58 \pm 3.13$ & $38.10 \pm 0.74$ \\
\cline { 2 - 5 } & Autumn & $1.69 \pm 0.32$ & $69.80 \pm 4.11$ & $38.78 \pm 0.72$ \\
\hline
\end{tabular}
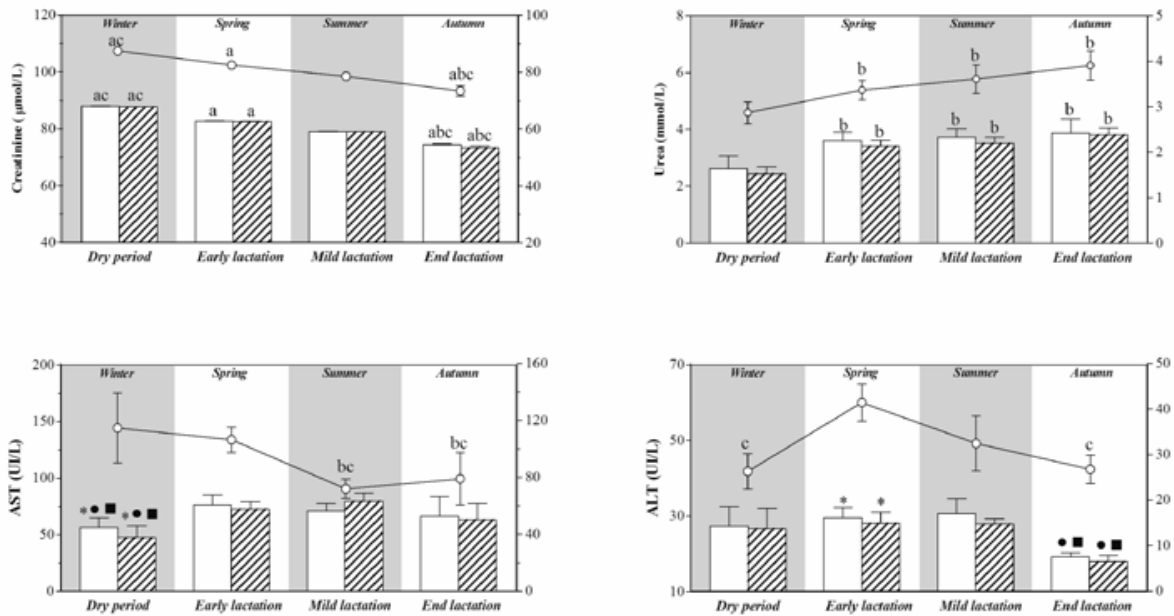

Significant effect of season $(P<0.05):{ }^{\mathrm{a}}$ vs Summer; ${ }^{\mathrm{b}}$ vs Winter; ${ }^{\mathrm{c}}$ vs Spring

Significant effect of reproductive status $(P<0.05): \bullet$ vs Early lactation; * vs Mild lactation $\square$ Group A $\square$ Group B - - Group C Significant effect of gender $(P<0.05)$ : * vs Group C

Fig. 3. Mean values \pm standard deviation ( \pm SD) of serum creatinine, urea, aspartate aminotransferase (AST) and alanine aminotransferase (ALT) concentrations obtained from dairy cows in the first lactation class (Group A), cows in the third lactation class (Group B) and bulls (Group C) during the monitored period (winter - dry period; spring - early lactation; summer mild lactation; autumn - end lactation) with the related statistical significances. 
R. D. Cerutti et al.: Effect of season on some hematochemical parameters in Holstein bovine
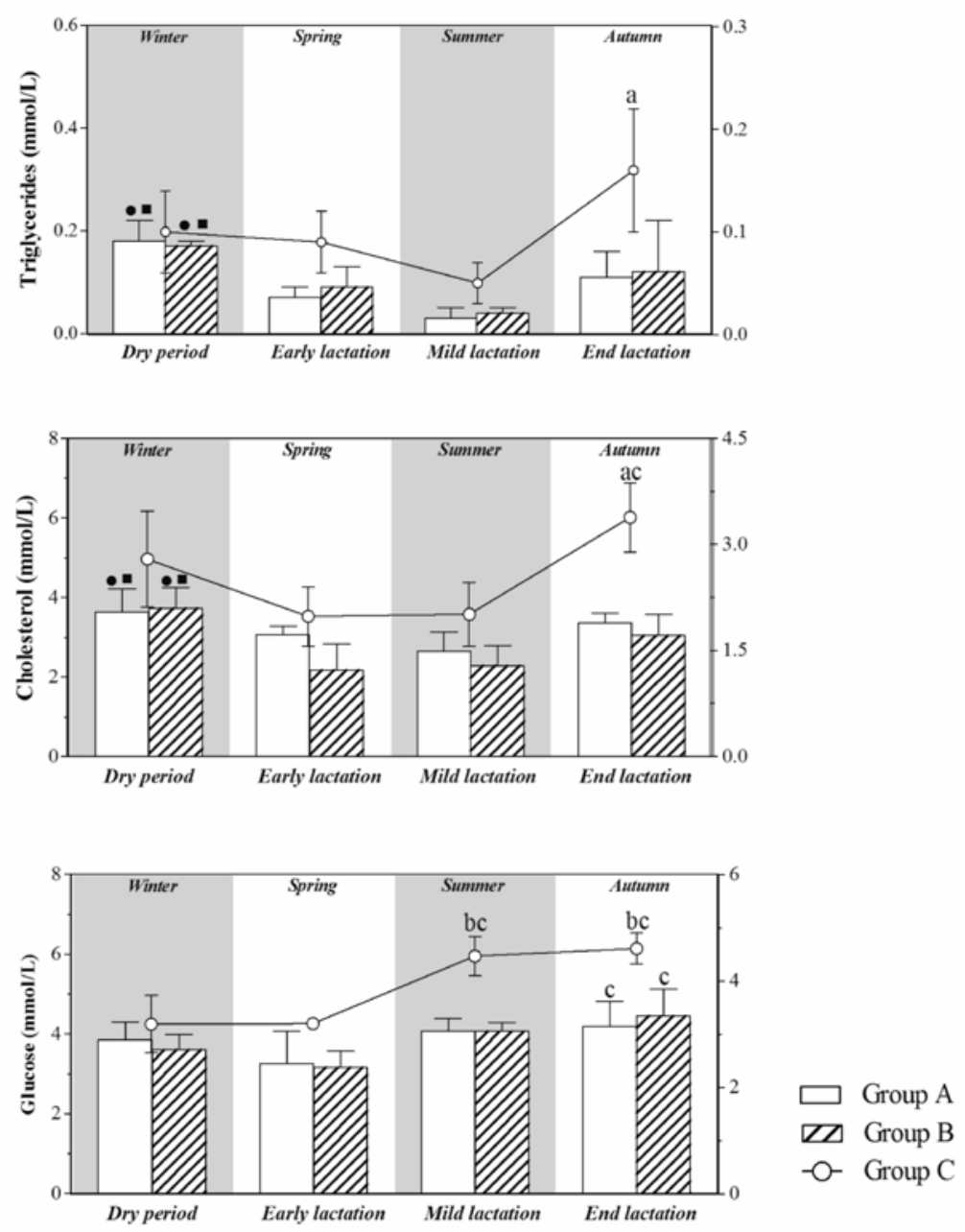

Significant effect of season $(P<0.05):{ }^{a}$ vs Summer; ${ }^{\mathrm{b}}$ vs Winter; ${ }^{\mathrm{c}}$ vs Spring Significant effect of reproductive status $(P<0.05)$ : • vs Early lactation; - vs Mild lactation

Fig. 4. Mean values \pm standard deviation ( \pm SD) of serum triglycerides, cholesterol and glucose concentrations obtained from dairy cows in the first lactation class (Group A), cows in the third lactation class (Group B) and bulls (Group C) during the monitored period (winter - dry period; spring - early lactation; summer - mild lactation; autumn - end lactation) with the related statistical significances. 


\section{Discussion}

Blood parameters are an important tool that helps dairy practitioners to monitor cow health at the individual and herd level (RAMPRABHU et al., 2010). The serum vitamin, protein and lipid concentrations are highly affected by diet. In a study on the effects of seasonal variations on the serum chemistry, it was stated that the obtained results might be misleading due to dietary supplementation (SWANSON et al., 2004). In this investigation, the nutritional management of the dairy cattle did not include supplemented diet. Thus, the serum chemistry reflects the productive status and seasonal variables more accurately. Environmental stress exerts a pronounced effect on the various biochemical characteristics of the blood (MAZZULLO et al., 2014). The environmental temperature and THI recorded in spring were within the upper critical zone. The ideal environmental temperature for a cow, known as the thermoneutral zone, is between $5{ }^{\circ} \mathrm{C}$ and $25^{\circ} \mathrm{C}$ (ROENFELDT, 1998). As environmental temperature increases, it becomes more difficult for cattle to cool their bodies adequately and heat stress occurs. THI values of 70 or less are considered comfortable, 75-78 stressful, and values greater than 78 cause extreme distress, with lactating cows being unable to maintain thermoregulatory mechanisms or normal body temperatures (KADZERE et al., 2002). In order to understand clearly which affects the serum chemistry values, season of the year or productive status conditions, bulls and cows in first and third lactation classes were considered. According to our results, the serum levels of glucose, creatinine and urea showed significant and consistent seasonal variations in both bulls and dairy cows, and there were no significant differences observed between the groups for these variables. As total proteins and albumin values were unaffected by season, the seasonal differences observed in the values of glucose, creatinine and urea were not a consequence of dehydration. In this study, increased urea values were found in spring, summer and autumn seasons, whereas an opposite trend was found for creatinine levels. The urea and creatinine trends suggest higher utilization of aminoacids through mobilization of muscle as an energy source in spring, summer and autumn in comparison with winter (KOUBKOVÁ et al., 2002). In warm seasons a peripheral vasodilatation occurs in order to allow loss of body heat through sweating, and this may therefore reduce the blood flow to the internal organs including the kidneys. This could influence the renal excretion of urea and creatinine. The rate of excretion of creatinine is influenced by the glomerular filtration rate, and creatinine is eliminated more easily than urea (GUYTON and HALL, 1996), which could explain the opposite trends found for these parameters. Both bulls and dairy cows showed lower glucose levels in winter and spring compared to summer and autumn. Despite the significant changes found in the seasons, the glucose values were within the reference range suggested for cattle (KANEKO, 1997). It is known that serum glucose in bovine species is probably derived almost exclusively from gluconeogenesis; therefore, the lower glucose concentration found in winter and summer suggest that gluconeogenesis is less effective in increasing 
blood glucose in these seasons than in other periods (ALBERGHINA et al., 2013). The rise in glucose levels in summer and autumn might also be attributed to a compensatory metabolic response to changing temperatures and humidity, and energy loss, also reported in sheep and heifers (SINGH and SINGH, 2005; KULKARNI et al., 2010). Moreover, the increased energy demand associated with an increased respiration rate, along with a possible decrease in feed intake during cooler and warmer seasons compared to the more temperate time of year, might have caused mobilization of body fat reserves to increase the plasma glucose levels as measured in summer and autumn (SRIKANDAKUMAR and JOHNSON, 2004). The fat mobilization and lipolysis could explain the seasonal changes found in triglyceride and cholesterol values found only in bulls. The lack of seasonal effect on lipids in dairy cows in the first and third lactation classes could be due to their productive status. Particularly, the metabolic adjustments occurring in lactating animals in order to cope with their energy demands may have masked the effect of the season. The results obtained in this study showed that AST and ALT values were influenced by season in bulls. AST showed higher values in spring and winter compared to summer and autumn, whereas ALT values were higher in spring than in winter and autumn. The increase in the activities of these enzymes is mainly due to the leakage of these enzymes from the liver cytosol into the blood stream, which reflects liver damage and disruption of normal liver function (MAZZULLO et al., 2014). Contradictory results about seasonal changes in AST and ALT values can be found in the literature. It was reported that during the summer an increase in transaminase enzyme activity occurred in the serum (MARAI et al., 1995, 1997). In contrast, other authors reported that hepatic enzyme activities decreased during heat exposure (RONCHI et al., 1999; KOUBKOVÁ et al., 2002).

Regarding blood minerals, the serum levels of $\mathrm{Mg}$ showed significant and consistent seasonal variations in both bulls and dairy cows, whereas the values of $\mathrm{Ca}, \mathrm{K}$ and $\mathrm{Na}$ followed a seasonal variation only in Group $\mathrm{C}$. Along with water, $\mathrm{Mg}, \mathrm{K}$ and $\mathrm{Na}$ are important constituents of sweat, and sweating is a major thermoregulatory mechanism to dissipate excess body heat when animals are exposed to a warmer environment (KADZERE et al., 2002). This acclimation strategy could explain the lower mean values for these parameters recorded in the spring and summer seasons. The serum Ca level is controlled by the parathyroid hormone, which acts on bones and kidneys to keep calcium levels constant. The parathyroid gland monitors the blood calcium concentrations in the carotid artery, and secretes the parathyroid hormone, which immediately increases the renal calcium reabsorption mechanism, resulting in decreased urinary calcium loss (REECE, 2005). The higher Ca levels found in winter might be due to excessive secretion of the parathyroid hormone in the cold season. The Ca values measured in each group in the summer season, as well as the $\mathrm{Mg}$ values measured in each group in the spring season, were outside the reference range suggested for bovine species (KANEKO, 1997), suggesting that the homeostasis of these minerals in the body of the 
animals was disturbed. However, the values of the other minerals studied fell within the reference range suggested for cattle (KANEKO, 1997). These findings seem to suggest that the cattle studied are adapted to the levels prevailing in the pasture available to them. However, they could require dietary supplementation of $\mathrm{Mg}$ and $\mathrm{Ca}$ in the spring and summer seasons, respectively. The results of the present study showed the significant effect of gender on both AST and ALT values. AST and ALT values were lower in dairy cows in their first and third lactation compared to males in winter and spring, respectively. Liver enzymes have an extracellular function and, thus, occur in low quantities with increases signifying damage in the tissues in which they are lodged. The concentration of serum enzymes reflects enzymes that are either in transit from the site of synthesis to the site of action, or which have been released from the damaged cells (GRÜNWALDT et al., 2005). Even productive status showed a significant influence on these liver enzymes, as well as on the values of $\mathrm{Ca}$, triglycerides and cholesterol. The changes found in these parameters could be related to the different stages of lactation. The Ca showed higher values in early lactation and at the end of the lactation period in comparison with mild lactation. This electrolyte plays a key role in several body functions such as bone and energy metabolism, and it comprises about $70 \%$ of the mineral content of the body and up to $50 \%$ of the minerals in milk. Dairy cows in first and third lactation showed higher triglyceride and cholesterol levels and lower AST values, in the dry period in comparison with early and mild lactation. However, the ALT values showed were higher in the early and mild lactation periods in comparison to the end of lactation. The trends of triglyceride and cholesterol levels found in both dairy cow groups are in agreement with the findings of previous studies carried out on sheep, cows and mares (MARCOS et al., 1990; WATSON et al., 1993; NAZIFI et al., 2002), reporting that there is a strong reduction in lipogenesis during the lactation period. During the late-pregnancy and lactation periods the number of total insulin receptors decreases, and the insulin stimulation of lipogenesis becomes inefficient (GUESNET et al., 1991). Therefore, the decreased triglyceride levels could be related to the increase in insulin resistance. The increased levels of triglyceride and cholesterol found at the end of lactation in both cow groups may depend on hepatic apolipoprotein synthesis caused by estradiole (BURTIS and ASHWOOD, 1999).

\section{Conclusions}

Endogenous and exogenous factors have to be taken into consideration for a correct interpretation of serum chemistry in cattle in order to establish an accurate interpretation of laboratory data, which is critical in the diagnosis, prognosis and treatment of diseases in cattle. The results obtained in the present study showed that gender, productive status and environmental variables significantly influence biochemical parameters in bulls and dairy cows. Therefore, nutritional supplements are often required for cattle during certain periods to avoid a decline in their performance, which would then result in economic loses. 
R. D. Cerutti et al.: Effect of season on some hematochemical parameters in Holstein bovine

\section{References}

AlberghinA, D., G. PICCIONE, S. CASElla, M. PANZERA, M. MORGANTE, M. GIANESELLA (2013): The effect of the season on some blood metabolites and haptoglobin in dairy cows during postpartum period. Arch. Tierz. 56, 354-359.

ARFUSO, F., F. FAZIO, M. LEVANTI, M. RIZZO, S. DI PIETRO, E. GIUDICE, G. PICCIONE (2016): Lipid and lipoprotein profile changes in dairy cows in response to late pregnancy and the early postpartum period. Arch. Tierz. 59, 429-434.

BURTIS, C. A., E. R. ASHWOOD (1999): Tietz Textbook of Clinical Chemistry. $3^{\text {rd }}$ ed., W.B. Saunders Company, Philadelphia.

GRÜNWALDT, E. G., J. C. GUEVARA, O. R. ESTÉVEZ, A. VICENTE, H. ROUSSELLE, N. ALCUTEN, D. AGUERREGARAY, C. R. STASI (2005): Biochemical and haematological measurements in beef cattle in Mendoza plain rangelands (Argentina). Trop. Anim. Health Prod. 37, 527-540.

GUESNET, P. M., M. J. MASSOUD, Y. DEMARNE (1991): Regulation of adipose tissue metabolism during pregnancy and lactation in the ewe: the role of insulin. J. Am. Sci. 69, 2057-2065.

GUYTON, A. C., J. E. HALL (1996): Text Book of Medical Physiology. $9^{\text {th }}$ ed., W.B. Saunders Company, Philadelphia.

HERDT, T. H. (2000) Variability characteristics and test selection in herd-level nutritional and metabolic profile testing. Vet. Clin. North Am. Food Anim. Pract. 16, 387-403.

KADZERE, C. T., M. R. MURPHY, N. SILANIKOVE, E. MALTZ (2002): Heat stress in lactating dairy cows: a review. Livest. Prod. Sci. 77, 59-91.

KANEKO, J. J. (1997); Appendix VIII: blood analyte reference values in large animals. In: Clinical biochemistry of domestic animals, $5^{\text {th }}$ ed. (Kaneko, J. J., J. W. Harvey, M. L. Bruss, Eds.). Academic Press Inc., San Diego, pp. 890-894.

KOUBKOVÁ, M., I. KNÍŽKOVÁ, P. KUNC, H. HÄRTLOVÁ, J. FLUSSER, O. DOLEŽAL (2002): Influence of high environmental temperatures and evaporative cooling on some physiological, hematological and biochemical parameters in high-yielding dairy cows. Czech J. Anim. Sci. 47, 309-318.

KULKARNI, S. S., N. Z. GAIKWAD, S. T. BAPAT (2010): Effect of summer season on certain biochemical parameters in Deccani sheep. Ind. Vet. J. 87, 729-730.

MAFFA, MAFF, Ministery of Agriculture Fisheries and Food (1989): Manual of Veterinary Laboratory Diagnostic Techniques. Reference Book No. 418. Her Majesty's Stationery Office, London.

MARAI, I. F. M., A. A. HABEEB, A. H. DAADER, H. M. YOUSEF (1995): Effects of Egyptian subtropical summer conditions and the heat-stress alleviation technique of water spray and a diaphoretic on the growth and physiological functions of Friesian calves. J. Arid Environ. 30, 219-225.

Vet. arhiv 88 (3), 309-321, 2018 
R. D. Cerutti et al.: Effect of season on some hematochemical parameters in Holstein bovine

MARAI, I. F. M., A. A. HABEEB, A. H. DAADER, H. M. YOUSEF (1997): Effects of diet supplementation and body cooling on Friesian calves reared in high ambient temperatures in the eastern desert of Egypt. Trop. Anim. Health Prod. 29, 201-208.

MARCOS, E., A. MAZUR, P. CARDOT, Y. RAYSSIGUIER (1990): The effect of pregnancy and lactation on serum lipid and apolipoprotein B and A-1 levels in dairy cows. J. Anim. Physiol. Anim. Nutr. 64, 133-138.

MAZZULlo, G., C. RIFICI, S. F. LOMBARDO, S. AGRICOLA, M. RIZZO, G. PICCIONE (2014): Seasonal variations of some blood parameters in cow. Large Anim. Rev. 20, 81-84.

MBASSA, G. K., J. S. D. POULSEN (2003): Reference ranges for clinical chemical values in Landrace goats. Small Rumin. Res. 10, 133-142.

NAZIFI, S., M. SAEB, S. M. GHAVAMI (2002): Serum lipid profile in Iranian fat-tailed sheep in late pregnancy, at parturition and during the post-parturition period. J. Vet. Med. 49, 9-12.

OPARA, M. N., N. UDEVI, I. C. OKOLI (2010): Haematological parameters and blood chemistry of apparently healthy west African Dwarf (Wad) goats in Owerri, South Eastern Nigeria. N. Y. Sci. J. 3, 68-72.

POTTER, C. F., K. L. JACOBSEN (2000): The reduction of heat stress in a herd of dairy cows in the north-east of the USA. Large Anim. Rev. 6, 35-41.

RAMPRABHU, R., M. CHELLAPANDIAN, S. BALACHANDRAN, J. J. RAJESWAR (2010): Influence of age and sex on blood parameters of Kanni goat in Tamil Nadu. Indian J. Small. Rumin. 16, 84-89.

REECE, W. O. (2005): Duke's Physiology of Domestic Animals. 12 $2^{\text {th }}$ ed., Panima Publishing Corporation, New Delhi.

ROENFELDT, S. (1998): You can't afford to ignore heat stress. Dairy Manag. 35, 6-12.

RONCHI, B., U. BERNABUCCI, N. G. LACETERA, A. V. SUPPLIZI, A. NARDONE (1999): Distinct and common effects of heat stress and restricted feeding on metabolic status of Holstein heifers. Zoot. Nutr. Anim. 25, 11-20.

SINGH R., S. V. SINGH (2005): Variations in cutaneous temperature, physiological responses and blood biochemical in Karan Fries and Sahiwal heifers during solar exposure in summer. Ind. J. Dairy Sci. 58, 415-419.

SRIKANDAKUMAR, A., E. H. JOHNSON (2004): Effect of heat stress on milk production, rectal temperature respiratory rate and blod chemistry in Holstein, Jersey and Australian Milking Zebu cows. Trop. Anim. Health Prod. 36, 685-692.

SWANSON, K. S., K. N. KUZMUK, L. B. SCHOOK, G. C. FAHEY (2004): Diet affects nutrient digestibility, hematology, and serum chemistry of senior and weanling dogs. J. Anim. Sci. 82, 1713-1724.

WATSON, T. D. G., L. BURNS, C. J. PACKARD, J. SHEPHERD (1993): Effects of pregnancy and lactation on plasma lipid and lipoprotein concentrations, lipoprotein composition and postheparin lipase activities in Shetland pony mares. J. Reprod. Fertil. 97, 563-568. 
R. D. Cerutti et al.: Effect of season on some hematochemical parameters in Holstein bovine

Received: 4 April 2017

Accepted: 15 September 2017

\section{CERUTTI, R. D., M. C. SCAGLIONE, F. ARFUSO, M. RIZZO, G. PICCIONE: Sezonske varijacije nekih hematokemijskih pokazatelja kod holštajnskih goveda držanih u istim uzgojnim uvjetima. Vet. arhiv 88, 309-321, 2018.}

\section{SAŽETAK}

Istražen je učinak sezone, spola i proizvodnog statusa na neke hematokemijske pokazatelje kod klinički zdravih holštajnskih goveda. Uključeno je ukupno 18 goveda koja su s obzirom na spol i laktaciju razvrstana u tri brojčano jednake skupine: skupina A (mliječne krave u prvoj laktaciji), skupina B (mliječne krave u trećoj laktaciji), skupina C (bikovi). Skupine A i B bile su u istom proizvodnom statusu (zasušenje zimi, rana laktacija u proljeće, srednja laktacija ljeti, završetak laktacije ujesen). Uzorci krvi prikupljeni su od životinja u istom satu (8.00) kontrolnog dana, u siječnju (zimska sezona), travnju (proljetna sezona), srpnju (ljetna sezona) i u listopadu (jesenska sezona). Analizirani su koncentracija glukoze, kalcija (Ca), magnezija (Mg), kalija (K), natrija $(\mathrm{Na})$, fosfora $(\mathrm{P})$, ukupnih bjelančevina, albumina, kreatinina, uree, aspartat-aminotransferaze (AST) i alanin-aminotransferaze $(A L T)$. Učinak sezone $(\mathrm{P}<0,05)$ utvrđen je za vrijednosti $\mathrm{Mg}$, kreatinina, uree $\mathrm{i}$ glukoze u svim skupinama. $\mathrm{Ca}$, Na, K, AST, ALT, trigliceridi i vrijednosti kolesterola bili su pod utjecajem sezone u skupini $\mathrm{C}(\mathrm{P}<0,05)$. Proizvodni status utjecao je na vrijednosti $\mathrm{Ca}$, AST, ALT, triglicerida i vrijednosti kolesterola $(\mathrm{P}<0,05)$ u skupinama A i B. Spol je imao značajan utjecaj na vrijednosti AST i ALT $(\mathrm{P}<0,05)$. Istraživanje pokazuje da za pravilno tumačenje kemijskih pokazatelja u serumu goveda treba uzeti u obzir sezonske i fiziološke uvjete, što pridonosi točnijem tumačenju laboratorijskih podataka važnih za dijagnozu, prognozu i liječenje bolesti.

Ključne riječi: goveda; biokemijski pokazatelji; spol; proizvodni status; sezona 
